\title{
Role of Epigenetic Modification, Epigenetic Biomarkers and Dietary Supplements in Neurodegenerative Diseases
}

\author{
Faiza Naseer* \\ Department of Pharmacy, University of Faisalabad, Pakistan
}

\begin{abstract}
Neurodegenerative diseases are outcome of epigenetic modification and environmental factors. With the age, due to epimutation neural cell get harm and affect the cognitive function. Epigenetic biomarkers such as DNA methylation, histone modification and miRNA alter the genes functions, involved in many cellular processes. Early detection of these biomarkers help in early diagnosis of diseases. In this article we have focus on how epigenetic alteration affects the expression of genes and epigenetic biomarkers help in earlier diagnosis. We also have focus on dietary supplements which help in slowing the progression of disease.
\end{abstract}

Keywords: Epigenetic biomarkers; Neurodegenerative diseases; Epigenetic modifications

\section{INTRODUCTION}

Neurodegenerative diseases like Parkinson's disease (PD), Alzheimer's disease (AD) and Huntington's disease (HD) start late in life and last for several years [1]. They have become the most serious problem in current era, whose detrimental effects increasing with age and become incurable due to continuous degradation of nerve cell by epigenetic modifications [2]. The description of biomarkers responsible for epigenetic modifications, risk factor, new therapeutic target as well as diagnosis is still complicated due to complex correlation between its genetic and environmental factors. Currently, there is no diagnostic test available for its earlier detection [3]. According to Harvard School of public Health and $\mathrm{WHO}$, neurodegenerative diseases will take 8th position for causing death in 2020 among other lethal diseases [4].

Emergence of different biomarkers in neurodegeneration field such as neuroimaging, genomics, clinical and biochemical has enabled us to diagnose these disorders to some extent and now a days, epigenomics serves as best among all diagnostic tool for understanding the epigenetic alterations [5]. So, dietary restriction as well as supplements rich in antioxidants, polyphenols etc. has neuroprotective effect and minimize the risk of neurodegenerative diseases [6].

\section{EPIGENETIC MECHANISM}

1. Epigenetic mutation refers to alteration in gene expression or function without disturbing DNA sequence, which mainly involve DNA hypo and hyper-methylation, post-modification of histone, and non-coding RNAs
[7]. Exogenous factors in combination with epigenetic mechanism altered the different genes expression, which leads to different diseases as shown in Figure 1 (Epigenetic biomarkers for early detection, therapeutic effectiveness, and relapse monitoring of cancer [8]. Epigenetic dysregulation in neurodegenerative diseases may be due to accumulation of intraneuronal plaques which interact with transcription and leads to dementia [5]. Exact mechanism of mutation that leads to neurodegeneration are not clearly understood.

Different hypothesis are available for pathogenic mechanism such as disease may be:

- Disturbance in biochemical pathways.

- Due to aggregation of mutated proteins, apoptosis as well as problem in transcription process and epigenetic mechanism [9-11].

Epigenetic mutation such as DNA methylation and histone modification are responsible for development of neurodegeneration. There is some epigenetic mechanism, mutation of which leads to neurodegeneration [12].

2. DNA methylation: Epigenetic mechanism involves the addition of methyl group at the position 5 in $\mathrm{CpG}$ dinucleotides. Normally CpG Island is unmethylated but it methylated as a result of epigenetic alteration and resulting in gene silencing [13].

I. Methylation of DNA also inhibits the transcription directly or indirectly. Indirectly inhibit the transcription by activating the methyl-CpG-binding domain proteins.

Correspondence to: Faiza Naseer, Department of Pharmacy, University of Faisalabad, Pakistan, Tel: +923333666515; E-mail: faiza.naseer@ymail.com

Received: March 14, 2019; Accepted: May 15, 2019; Published: May 22, 2019

Citation: Naseer F (2019) Role of Epigenetic Modification, Epigenetic Biomarkers and Dietary Supplements in Neurodegenerative Diseases. Health Care Current Reviews 7: 242. doi: 10.35248/2375-4273.19.7.242.

Copyright: (C) 2019 Naseer F. This is an open-access article distributed under the terms of the Creative Commons Attribution License, which permits unrestricted use, distribution, and reproduction in any medium, provided the original author and source are credited. 


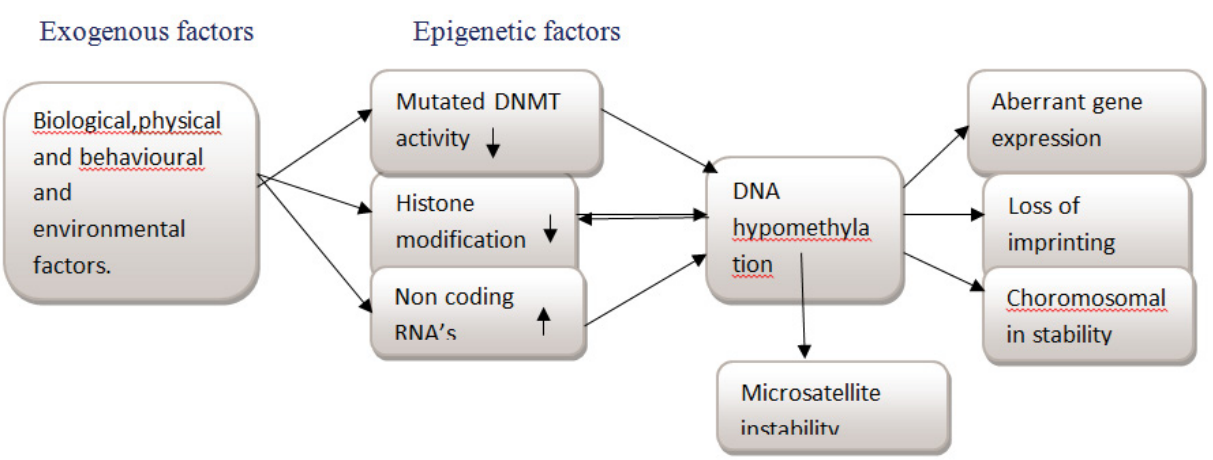

Figure 1: Showed that combination of environmental factors and genetic factors leads to epimutation (altered the gene expression) which ultimately result in disease state.

Directly inhibit the transcription by interfering the binding of DNA binding proteins at their specific sites. DNA methyltransferase enzymes such as DNMT1, DNMT3a and DNMT3b also responsible DNA methylation [14].

II. Histone modification: Octamer of core histones proteins form the nucleosome. Group of 4 core histones includes $\mathrm{H} 2 \mathrm{~A}, \mathrm{H} 2 \mathrm{~B}, \mathrm{H} 3$ and $\mathrm{H} 4$ which form $\mathrm{H} 2 \mathrm{~A}$ and $\mathrm{H} 2 \mathrm{~B}$ dimmers and one $\mathrm{H} 3-\mathrm{H} 4$ tetramer. These proteins play an important role for DNA helix. Posttranslational modifications of histone proteins such as methylation, sumoylation, phosphorylation and actylation are due to epigenetic mutation [15]. Posttranslational modification is reversible process [16]. Histone acetyl transferases (HATs) enzyme also responsible for histone modification. De novo methylation as a result of mutation is due to interaction of DNA methyltransferase 3 (DNMT3L) with histone $\mathrm{H} 3$ tails (H3K4).

III. RNA-based mechanism: Micro RNA leads to posttranscriptional gene silencing as a result of epigenetic mechanism. In addition of gene silencing micro RNA also activate the genes involve in proliferation and differentiation [3].

Aberrant epigenetic post-translational modifications of proteins are emerging as important elements in the pathogenesis of neurological disease [17]. Epigenetic mutation altered the gene expression by methylation in $\mathrm{CpG}$ islands of relevant genes. Due to difficulty in getting the brain tissue for diagnosis, it can be possible to observe the transcriptomic changes in blood of disease patients. Alteration of gene expression due to epimutation helps in diagnosis of disease [5].

\section{EPIGENETIC BIOMARKER IN ALZHEIMER DISEASE}

In patients with Alzheimer's disease protein aggregates found in brain cells. Epigenetic modification play an important role in pathogenesis of AD. Three genes altered in AD include Presenilin-1, PSEN-1, PSEN2 and amyloid beta A4 protein (APP). Increased level of phosphorylated histone $\mathrm{H} 3$ has been observed in hippocampal neuron in AD [18]. In AD temporal lobe histone acetylation found to be low as compared to normal person. miR-16 target the amyloid precursor protein and its expression is abnormally reduced in AD patients, which leads to protein accumulation [18]. MiR-124 also suppressed in AD brain. In AD NEP (neprily-sin) enzyme which is responsible for amyloid-beta degradation suppressed. Amyloid beta may also repress global hypo methylation (Figure 2) [5].

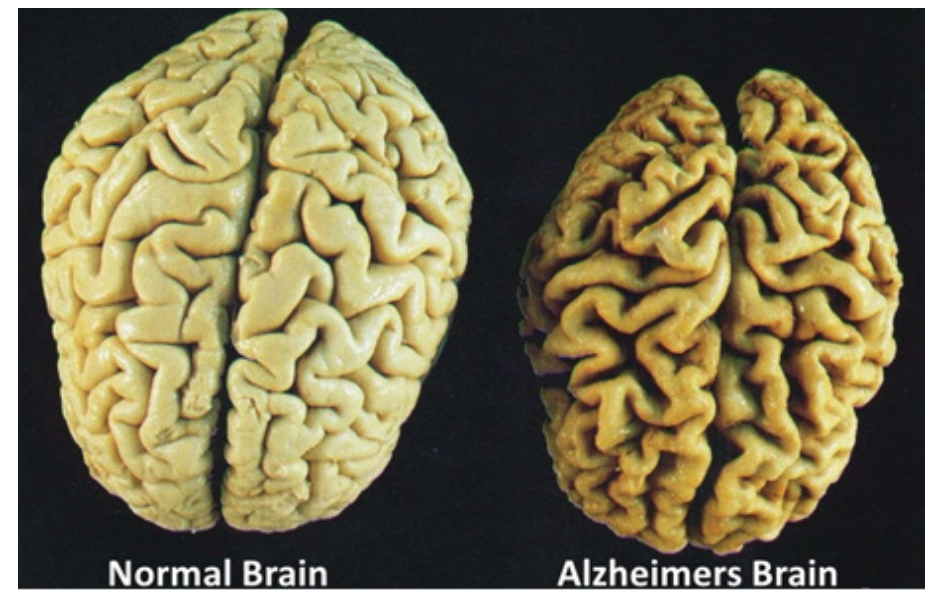

Figure 2: Epigenetic biomarker in Alzheimer's.

\section{EPIGENETIC BIOMARKER IN PARKINSON'S DISEASE}

Alzheimer disease and Parkinson disease are heterogeneous disease because they are combination of genetic and environmental factors. In early 1800 James Parkinson named the PD as "shaking palsy". Symptoms include muscle rigidity, postural instability, tremor and bradykinesia. In PD loss of neurons in substantia nigra due to aggregation of protein known as Lewy bodies [19]. Methylation of synuclein- $\alpha$ gene leads to accumulation of plaques in PD [20]. In PD alpha-synuclein decreased the level of acetylated histone $\mathrm{H} 3$ and inhibits histone acetyltransferase enzyme activity by binding to histone proteins [5]. Methylation of SNCA intron 1 leads to decreased in SNCA transcription, which has been observed in PD [21]. Genes such as ARK16, GPNMB and STX1B also show methylation in PD [22]. Hyermethylation of GRN gene has been observed in front temporal region of brain due to aberrant DNA methylation [23]. Decreased expression of miR-133b, miR-10a, $-212,-132,-7$ has also been observed in PD (Figure 3) [24-26].

\section{EPIGENETICS BIOMARKER IN HUNTINGTON'S DISEASE}

Normally huntingtin (htt) protein comprise of 36 polyQ repeats. In HD mutation leads to abnormal increased poly-glutamine (39 poly-Q) sequence of gene responsible for protein htt. miR-9, miR29b, miR-132 and miR-124a dysregulated in HD [27]. In blood and brain tissues of HD patient increased level of histone protein has been observed [4]. Epimutation altered the transcription as a result of increased histone methylation and decreased acetylation 
[28,29]. Localization of altered huntingtin to the nucleus form aggregates of mutated polyQ protein which ultimately inhibits the transcription factors (Figure 4) [30].

\section{EPIGENETIC BIOMARKER IN NEURODEGENERATIVE DISEASE}

Epigenetic mutation in different neurodegenerative diseases (Table 1) [31].

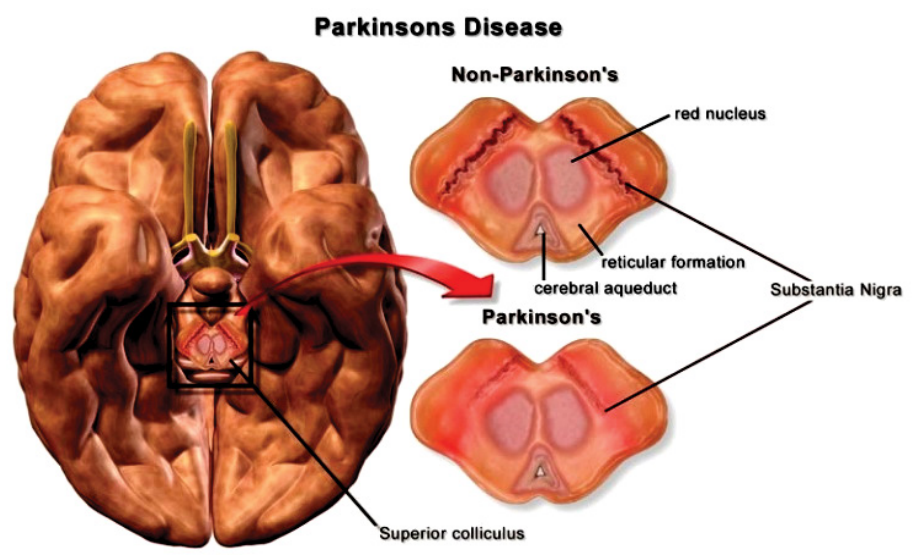

Figure 3: Epigenetic biomarker in Parkinson's.
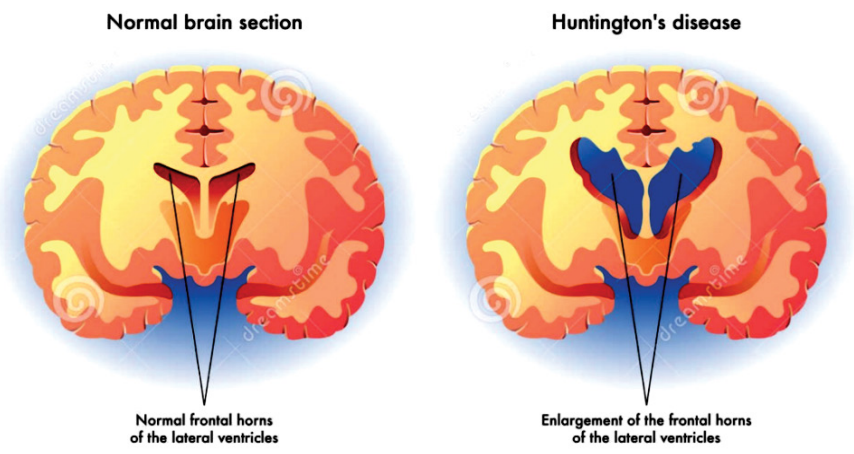

Figure 4: Epigenetic biomarker in Huntington's.

\section{TREATMENT OF NEURODEGENERATIVE DISEASE THROUGH DIET}

With the passage of time, in brain cells energy metabolism is impaired due to accretion of damaged molecules [32]. Multiple factors involved in neurodegenerative disease which includes depletion of endogenous antioxidants, elevated of nitric oxide and iron, neurotoxicity due to glutamate, irregulation of ubiquitinproteasome system, presence of proapoptotic proteins leads to degeneration of neurons [5]. To compensate neuronal damage neurotrophic factors as well as cell protecting proteins such as antioxidant etc help to restore damage neuronal cells. To overcome this (damaged) lost, neurons may either produce new neurons or remodeling neuronal system. In case of failure to adapt the changes to overcome neuronal damage neurodegeneration occurred [32]. Neuroprotective factors may be helpful to combat with diseases such as Parkinson's disease, Alzheimer disease and Huntingtin disease. In this article we will focus on different dietary factors that prevent the occurrence of neurodegenerative diseases (Figure 5).

Dietary restriction, exercise, intellectual activity prevents the neuronal damage by mechanism (Figure 6) [32]

Green tea contain catechin polyphenols which as neuroprotective activity by involving different mechanism of action (Figure 7) [6]

Folic acid deficiency as well as increased level of homocysteine affect the nervous system. Homocysteine damaged neuronal cells by inducing oxidative stress. Folic acid deficiency and homocysteine elevated level stimulate neurodegenerative process. Vitamin E, lipoic acid, coenzyme Q10 and Ginko biloba extract help in treating neurodegenerative diseases. Vitamin E has antioxidant properly. It suppresses neurodegeneration repress lipid peroxidation as well as by maintaining cellular ion homeostasis (Figure 8).

Ubiquinone (coenzyme Q10) has antioxidant property. It exhibit it antioxidant property by improving mitochondrial function and prevent the neuronal damage. Hypoxia, glutamate damages the brain cells but lipoic acid prevents this damage by suppressing

Table 1: Epigenetic mutation in different neurodegenerative diseases.

\begin{tabular}{|c|c|c|c|}
\hline & DNA Methylation & Histone Modification & Micro RNA Regulation \\
\hline \multirow{3}{*}{$\begin{array}{l}\text { Alzeihmiers } \\
\text { Disease }\end{array}$} & $\begin{array}{l}\text { Supressed DNA methylation in the } \\
\text { anterior neuronal nuclei }\end{array}$ & $\begin{array}{l}\text { Elevated phosphorylated histone } \\
\text { H3 in hippocampal neurons }\end{array}$ & $\begin{array}{c}\text { Dysregulation of mRNAs in } \\
\text { brain }\end{array}$ \\
\hline & Hypermethylation of HTERT gene & $\begin{array}{c}\text { Modulation of histone acetylation } \\
\text { by HDAC inhibitors }\end{array}$ & \\
\hline & $\begin{array}{l}\text { Hypomethylation of inflammatory } \\
\text { genes such as TNF, IL-1 in cortex }\end{array}$ & & \\
\hline \multirow{3}{*}{$\begin{array}{l}\text { Parkinsons } \\
\text { Disease }\end{array}$} & Methylation suppressed & $\begin{array}{l}\text { Alpha synuclein suppressed } \\
\text { histone acetylation as well as } \\
\text { histone gene expression }\end{array}$ & $\begin{array}{c}\text { Differential expression of } \\
\text { dopaminergic neuron specific } \\
\text { miRNA miR, }-133 \mathrm{~b}\end{array}$ \\
\hline & $\begin{array}{l}\text { Hypomethylation of SNCA gene } \\
\text { in brain tissue. Alpha synuclein } \\
\text { decreases the availability of Dnmt } 1 \\
\text { methyltransferase }\end{array}$ & & $\begin{array}{c}\text { Differential expression of } \\
\text { niR-7, }-132,-495,-10 \mathrm{a},-10 \mathrm{~b} \text { in } \\
\text { brain tissues }\end{array}$ \\
\hline & $\begin{array}{c}\text { Methylation of ARK16, CYP2E1 and } \\
\text { STX1B. Hypermethylation of GRN } \\
\text { gene }\end{array}$ & & \\
\hline \multirow{2}{*}{$\begin{array}{l}\text { Huntingtons } \\
\text { disease }\end{array}$} & Increased availability at HTT gene locus & $\begin{array}{c}\text { Sequestration of proteins it } \\
\text { HDAC activity }\end{array}$ & $\begin{array}{c}\text { Down regulation of nine } \\
\text { miRNA in HD }\end{array}$ \\
\hline & & $\begin{array}{l}\text { Elevation of histone proteins } \\
\text { carrying H3K9 marks in blood } \\
\text { and brain tissues }\end{array}$ & $\begin{array}{l}\text { Unregulation of miR-34b in } \\
\text { plasma of HD patient }\end{array}$ \\
\hline
\end{tabular}




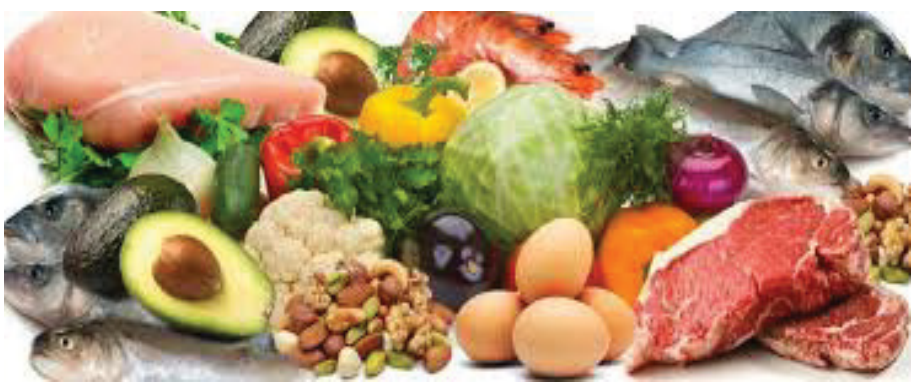

Figure 5: Diet of Neurodegenerative disease.

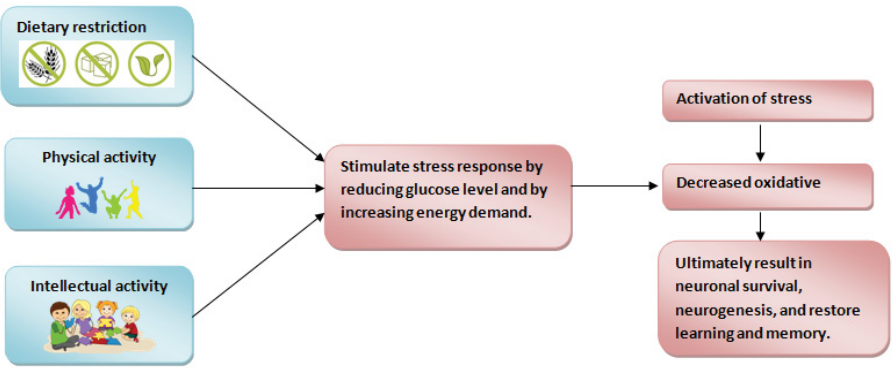

Figure 6: Dietary restriction, Exercise, Intellectual activity.
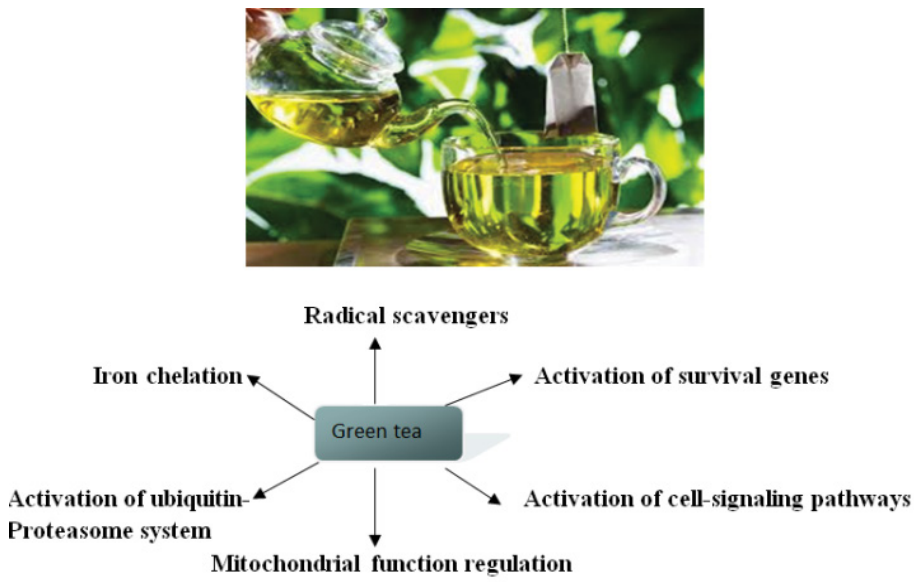

Figure 7: Polyphenols present in green tea help in preventing the neurodegeneration by different mechanism of action.

the ischemic brain injury. Lipoic acid also has ability to prevent neurodegeneration caused by $\mathrm{A} \beta$ [32].

$\mathrm{Zn}^{2+}$ deficiency induce neurodegeneration by formation of free radicles while it supplements prevent the neuronal damage [33].

Polyphenol known as resveratrol found in pomegranates, peanuts red wine has ability to abolish amyloid plaques formation. Recent study showed that resveratrol reduced the plaque formation in different areas of brain with different percentages such as in cortex (48\%), hypothalamus (90\%) and striatum (89\%). Dietary supplements with resveratrol also have ability in reducing the plaques formation by elevating the cysteine level as well as by decreasing the glutathione level [34]. Polyphenol in coca also has neuroprotective effect. Glutathione deficiency is hallmark of neurodegeneration disease. Glutathione is essential for normal function of brain cells. The most important factor responsible for glutathione depletion is monosodium glutamate (MSG) and aspartame. Dietary supplement such as magnesium remove metals and toxins from body by stimulating glutathione production. Diet rich in omega 3 fatty acid also help in reducing the neurodegeneration risk by $60 \%$ by suppressing the inflammation in brain cells (Figure 9) [34].

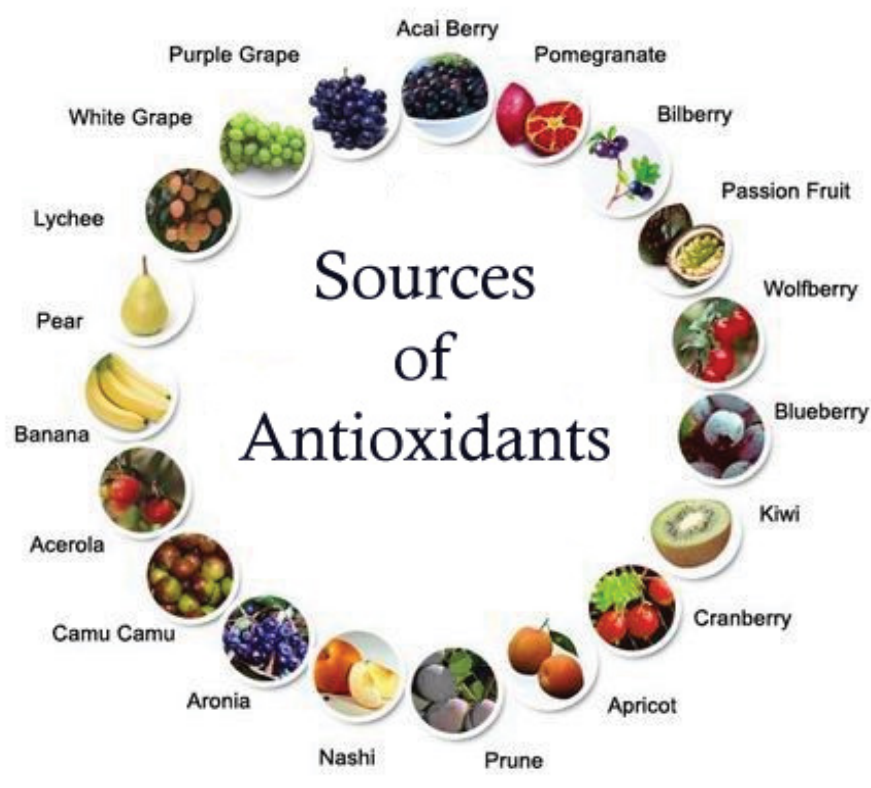

Figure 8: Sources of Antioxidants.

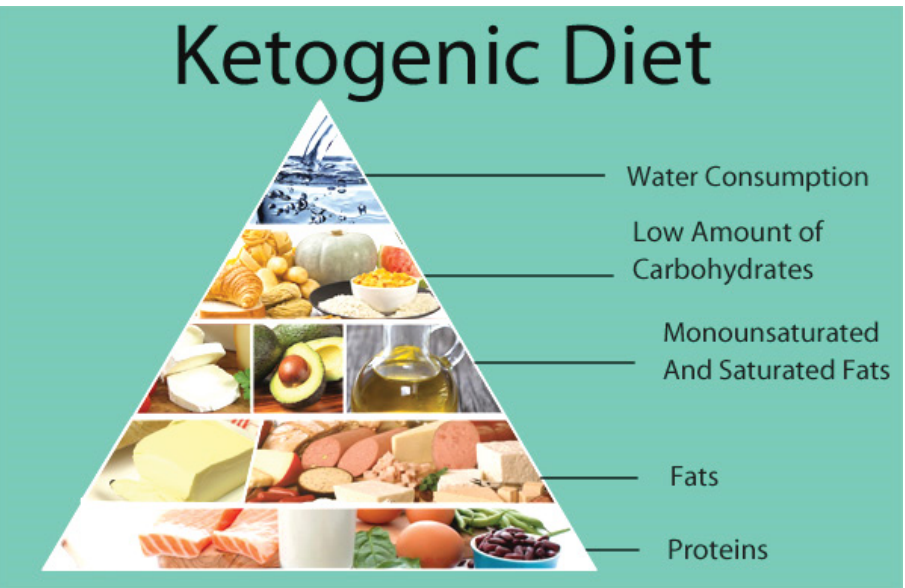

Figure 9: Ketogenic Diet.

Ketogenic diet improves glucose metabolism and metabolic dysfunction and protects the neuronal vells death by $\mathrm{A} \beta$ toxicity. With aging, glycation end product stored in brain cells where they induce oxidative stress and neurodegeneration. But KD prevent this damage because of it neuroprotective effect. KD also proved helpful against 6-hydroxydopamine neurotoxicity in PD by protecting the dopaminergic neurons in brain [26].

\section{CONCLUSION}

Neurodegenerative diseases are becoming important now a day. Multiple factors are involved in neuronal damage which includes environmental factors as well as epigenetic modification. Early detection of epigenetic modification helps in early diagnosis of neurodegenerative diseases. Epigenetic modification altered directly or indirectly transcriptional activity and posttranslational activity. Epigenetic modification is reversible phenomenon. Early understanding of epigenetic biomarker involved in neurodegeneration may open path of novel therapies for its treatment and prevent its progression. Now a day, dietary supplement not only help in disease prevention but also slow the progression of disease and prevent neuronal damage. So, it is important to improve our knowledge not only about epigenetic biomarkers but also about dietary supplement to prevent the generation and to slow the progression of disease. 


\section{REFERENCES}

1. Doxakis E. Post-transcriptional regulation of $\alpha$-synuclein expression by mir-7 and mir-153. J Biol Chem. 2010;285(17):12726-12734.

2. Colburn WA, DeGruttola VG, DeMets DL, Downing GJ, Hoth DF, Oates JA, et al. Biomarkers and surrogate endpoints: Preferred definitions and conceptual frame work. Clin Pharmacol Ther. 2001;69:89-95.

3. Espada J, Ballestar E, Santoro R, Fraga MF, Villar GA, Nemeth A, et al. Epigenetic disruption of ribosomal RNA genes and nucleolar architecture in DNA methyltransferase 1 (Dnmt1) deficient cells. Nucleic Acids Res. 2007;35(7):2191-2198.

4. Desplats P, Spencer B, Coffee E, Patel P, Michael S, Patrick C, et al. $\alpha$-Synuclein Sequesters Dnmt1 from the Nucleus A novel mechanism for epigenetic alterations in Lewy body diseases. J Biol Chem. 2011;286(11):9031-9037.

5. Esteller M. Epigenetic gene silencing in cancer: The DNA hypermethylome. Human Molecular Genet. 2007;16(1):50-59.

6. Stack EC, Del Signore SJ, Luthi CR, Soh BY, Goldstein DR, Matson S, et al. Modulation of nucleosome dynamics in Huntington's disease. Human Molecular Genet. 2007;16(10):1164-1175.

7. Feng Y, Jankovic J, Wu YC. Epigenetic mechanisms in Parkinson's disease. J Neurol Sci. 2015;349(1):3-9.

8. http://www.google.com/patents/US20100151468

9. Gillardon F, Mack M, Rist W, Schnack C, Lenter M, Hildebrandt T, et al. MicroRNA and proteome expression profiling in earlysymptomatic $\alpha$-synuclein (A30P) -transgenic mice. Proteo Clin Appl. 2008;2(5):697-705.

10. Gray SG. Epigenetic treatment of neurological disease. Epigenom. 2011;3(4):431-450.

11. Harjes P, Wanker EE. The hunt for huntingtin function: Interaction partners tell many different stories. Trends Biochem Sci. 2003;28(8):425-433.

12. He F, Todd PK. Epigenetics in nucleotide repeats expansion disorders. Neurol. 2011;31(5):470-483.

13. http://nutri.com/blog/2013/04/prevention-ofneurodegenerative-disease

14. Jowaed A, Schmitt I, Kaut O, Wüllner U. Methylation regulates alpha-synuclein expression and is decreased in Parkinson's disease patients' brains. J Neurosci. 2010;30(18):6355-6359.

15. Junn E, Lee KW, Jeong BS, Chan TW, Im JY, Mouradian MM. Repression of $\alpha$-synuclein expression and toxicity by microRNA-7. Nation Acad Sci. 2009;106(31):13052-13057.

16. Kaidery NA, Tarannum S, Thomas B. Epigenetic landscape of Parkinson's disease: Emerging role in disease mechanisms and therapeutic modalities. Neurother. 2013;10(4):698-708.

17. Karuppagounder SS, Pinto JT, Xu H, Chen HL, Beal MF, Gibson GE. Dietary supplementation with resveratrol reduces plaque pathology in a transgenic model of Alzheimer's disease. Neurochem Int. 2009;54(2):111-118.
18. Kouzarides T. Chromatin modifications and their function. Cell. 2007;128(4):693-705.

19. Mandel S, Youdim MB. Catechin polyphenols: neurodegeneration and neuroprotection in neurodegenerative diseases. Free Radical Biol Med. 2004;37(3):304-317.

20. Mattson MP, Chan SL, Duan W. Modification of brain aging and neurodegenerative disorders by genes, diet, and behavior. Physiol Rev. 2002;82(3):637-672.

21. Mendioroz IM, Pulido FL, Mendez Lopez I. Neuroepigenetics: Desoxyribonucleic acid methylation in Alzheimer's disease and other dementias. Med clin. 2015;144(10):457-464.

22. Menken M, Munsat TL, Toole JF. The global burden of disease study: Implications for neurology. Arch Neurol. 2000;57(3):418420.

23. Murray CJL, Lopez AD. The global burden of disease. 1996;201246.

24. Ogawa O, Zhu X, Lee HG, Raina A, Obrenovich ME, Bowser $\mathrm{R}$, et al. Ectopic localization of phosphorylated histone $\mathrm{H} 3$ in Alzheimer's disease: A mitotic catastrophe? Acta Neuropathol 2003;105(5):524-528.

25. Packer AN, Xing Y, Harper SQ, Jones L, Davidson BL. The bifunctional microRNA miR-9/miR-9* regulates REST and CoREST and is downregulated in Huntington's disease. J Neurosci. 2008;28(53):14341-14346.

26. Paoli A, Bianco A, Damiani E, Bosco G. Ketogenic diet in neuromuscular and neurodegenerative diseases. Bio Med Res Int. 2014

27. Ryu H, Lee J, Hagerty SW, Soh BY, McAlpin SE, Cormier $\mathrm{KA}$, et al. ESET/SETDB1 gene expression and histone H3 (K9) trimethylation in Huntington's disease. Nation Acad Sci. 2006;103(50):19176-19181.

28. Santos-Rosa H, Kirmizis A, Nelson C, Bartke T, Saksouk N, Cote J, et al. (2009). Histone $\mathrm{H} 3$ tail clipping regulates gene expression. Nature Struct Mol Biol 2009;16(1):17-22.

29. Siegel GJ, Agranoff BW, Albers RW, Fisher SK, Uhler MD. Basic Neurochem. 1999.

30. Smith P, Al Hashimi A, Girard J, Delay C, Hebert SS. In vivo regulation of amyloid precursor protein neuronal splicing by microRNAs. J Neurochem. 2011;116(2):240-247.

31. Lovrecic, L, Maver A, Zadel M, Peterlin B. The Role of Epigenetics in Neurodegenerative Diseases. 2013.

32. Spillantini MG, Schmidt ML, Lee VMY, Trojanowski JQ, Jakes R, Goedert M. $\alpha$-Synuclein in Lewy bodies. Nature, 1997;388(6645):839-840.

33. Straussman R, Nejman D, Roberts D, Steinfeld I, Blum B, Benvenisty $\mathrm{N}$, et al. Developmental programming of $\mathrm{CpG}$ island methylation profiles in the human genome. Nature Struct Mol Biol. 2009; 16(5):564-571.

34. Sugars KL, Rubinsztein DC. Transcriptional abnormalities in Huntington disease. Trends Gene. 2003;19(5):233-238. 